\title{
Identification of Contamination Recharge Area of Bribin-Baron Karst Water System, Gunung Sewu, Indonesia
}

\author{
by Tjahyo Nugroho Adji (1), M. Widyastuti (1), Sudarmadji (1), Eko Haryono (1)
}

(1) Faculty of Geography, Gadjah Mada University, Yogyakarta, Indonesia, 55281, adji@geo.ugm.ac.id

\begin{abstract}
This research area is located within the most essential underground river system of Gunung Sewu Karst, Indonesia. The water sampling focused on Bribin Cave and Baron Resurgence, where around 300.000 of people depend on this system. Timeseries water sampling was conducted to assess the contaminant composition within the system. In addition, another objective is to identify the possible contamination recharge area of this system.

Several samples have been analyzed to identify the contaminations in the underground river. In addition, geomorphological approach and field survey were conducted to describe the potential recharge area of the system including catchments of autogenic / allogenic stream and the spatial distribution of sinkholes around the system. Afterwards, the sanitation procedure of waste disposal in the recharge area is also evaluated.

The result shows that nitrate, heavy metals, and coli bacteria contaminated some samples over the whole time. The investigation also confirms that there are three possible contaminations of the recharge: (1) urban activity in Wonosari Basin, (2) settlement inside the conical karst, and (3) usage of fertilizer within the karst valley farmland adjacent to the sinkholes. Next, the most intensive source of contamination is the way in which Wonosari City residents dispose their waste without treatment into the allogenic river.
\end{abstract}

\section{Introduction}

Gunung Sewu is the name of the most spectacular tropical karst region in Indonesia, which is firstly introduced by Lehman (1936) who also geomorphologically declared the unique value of this region as "Gunung Sewu" type. This karst region is characterized by thousands of conical hills (kegel karst), caves, sinks and dolines that are continuously wet throughout the year. Some articles described the distinctive of this karst area i.e. Kusumayuda and Zen (2000), Urushibara and Yoshino (1995), Haryono and Day (2004).

In this area, around 300,000 residents depend on the Bribin-Baron underground river system to supply their water requirement, while its quantity is constantly insufficient during dry season due to the inappropriate pumping method (Adji and Nurjani, 1999; Adji, 2010 ). For information, the annual average discharge in Bribin Cave and Baron Resurgence is approximately 1000 lps (low) and 8000 lps (high), respectively. Recently, a collaboration of Indonesian and German government is constructing the underground dam by micro-hydro pumping technique to improve the capacity of pumping water from Bribin River.

On the other hand, some unpublished investigations confirm that Bribin water is already contaminated. The sources of contaminants are the waste disposals of Wonosari urban area and its adjacent. According to the above background, this research is aimed to (1) understand the type of contaminant and its sources and (2) to identify the surface recharge area of contamination sources.

\section{Materials and methods}

Material used in this research are (1) panchromatic aerial photos to delineate the catchment of surface recharge areas of Bribin-Baron system, (2) water samples from some locations along Bribin-Baron systems; including water quality samples from underground river, surface water before entering the sinkholes, domestic waste disposal, and waste disposal from hospital in Wonosari City. Moreover, parameters of water quality were analyzed in laboratory i.e. $\mathrm{NO}_{3}, \mathrm{NO}_{2}$, $\mathrm{BOD}, \mathrm{COD}$, heavy metals $\left(\mathrm{Cr}_{6}, \mathrm{Cd}, \mathrm{Zn}, \mathrm{Cu}, \mathrm{Pb}\right)$, and coli bacteria.

Water sampling was carried out on a temporal basis (3 times in a year) for surface and underground river. In addition, geomorphological approach is also conducted to define the catchment areas of allogenic rivers. Moreover, spatial analysis is performed to identify the mechanism of contaminant transport from recharge area to underground water system.

The contaminant source investigation within Bribin-Baron system is based on data that mainly originated from: (1) interview with the local residents, (2) field observation, (3) laboratory analysis of sampling water, and (4) interpretation of landuse distribution within recharge area.

\section{Results}

a. Bribin-Baron Surface Catchment

The occurrence of Bribin-Baron underground river system is mainly controlled by the geological structure of the underlying rocks (Kusumayuda \& Zen 2000; Haryono \& Adji 2004). Accordingly, the cave networks are concentrated in this zone. Bribin-Baron system is recharged by some allogenic and autogenic streams. The 
catchment boundaries of autogenic recharge areas are extremely difficult to define, while the boundary of allogenic catchment may be identified with the aid of aerial photo and topographic map interpretations. In this area, the main allogenic recharge of Bribin-Baron system seems to be the tributaries of Pentung, Tegoan, Sumurup and Suci River (Adji \& Sudarmadji, 2010 -Figure 1).

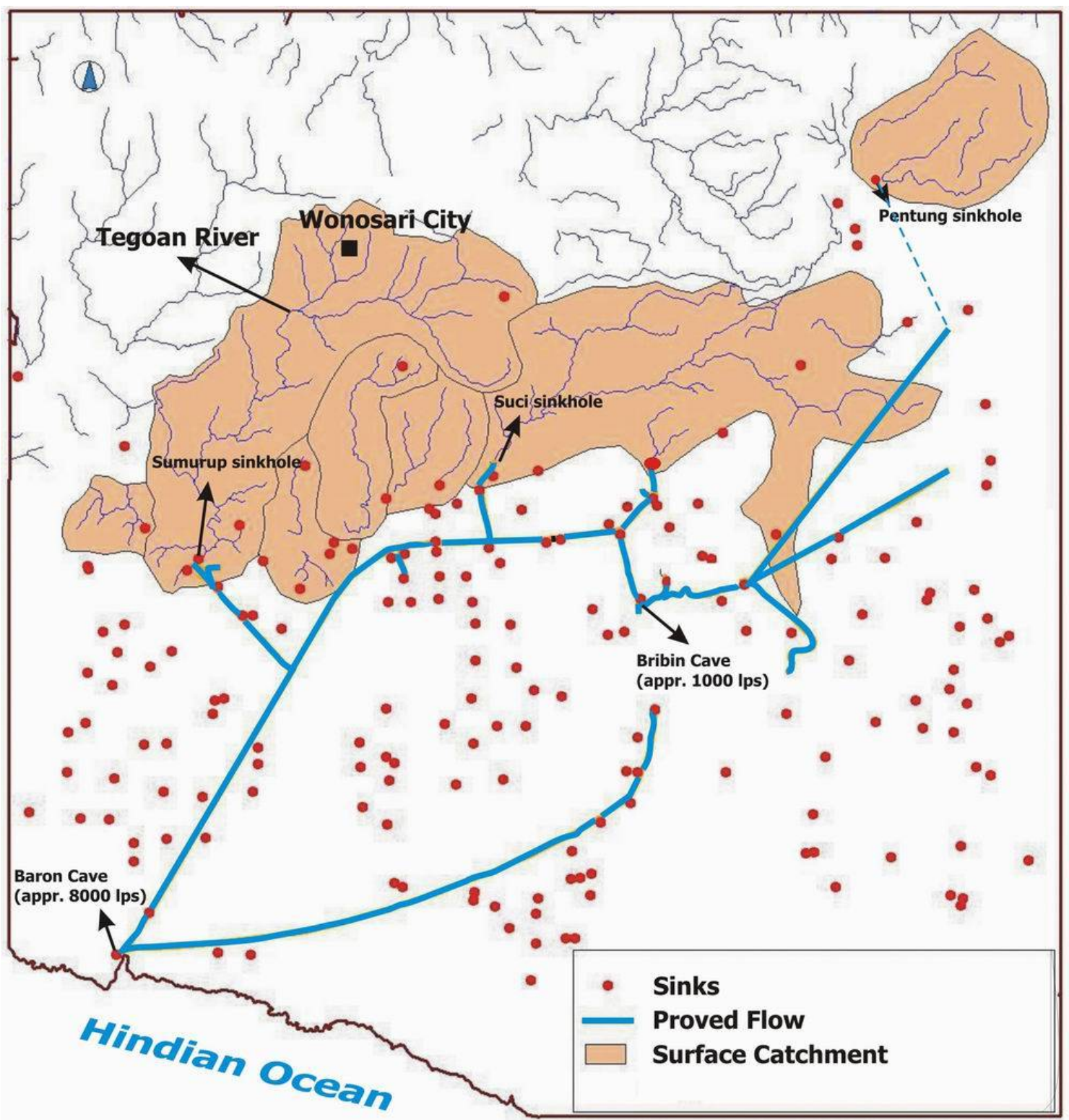

Figure 1. Possible recharge of Bribin-Baron Underground Water System

Therefore, the surface (allogenic) catchment areas are typically located in Wonosari Basin and drained into the underground system by Suci, Sumurup and Semuluh sinkholes, while the upper part, which is composed by volcanic clastic rocks, is drained by the sinkhole of Pentung River. According to McDonalds and Partners (1984), the percentage of surface recharge is approximately $22 \%$ of the total discharge of Bribin-Baron system, and the rest is contributed by recharge from the karst areas. In terms of recharge percentage, it seems that the contribution of allogenic recharge to the total outlet discharge is very small compared to that from autogenic input. However, the origin of contamination from allogenic recharge may be privileged due to the different anthropogenic conditions. 


\section{b. Contaminant analysis}

Contamination indicators as heavy metals $\left(\mathrm{Cu}, \mathrm{Zn}, \mathrm{Cd}, \mathrm{Pb}, \mathrm{Cr}_{6}\right), \mathrm{NO}_{3}, \mathrm{NO}_{2}, \mathrm{BOD}, \mathrm{COD}$, coli bacteria were analyzed. The results of laboratory analysis are presented in Table 1.

Table 1. Level of Contaminant in Bribin-Baron System

\begin{tabular}{|c|c|c|c|c|c|c|}
\hline Parameters & 1 & 2 & 3 & 4 & 5 & 6 \\
\hline \multicolumn{7}{|c|}{7 February 2005 (wet season) } \\
\hline $\mathrm{NO}_{3}$ & 1.6 & 4.4 & 2.6 & 2 & 4.2 & 3 \\
\hline $\mathrm{NO}_{2}$ & 0 & 0 & 0 & 0 & 0 & 0 \\
\hline $\mathrm{Cr}_{6}$ & 0 & 0.401 & 0.46 & 0.042 & 0 & 0.46 \\
\hline $\mathrm{Cu}$ & 0 & 0 & 0 & 0 & 0 & 0 \\
\hline $\mathrm{Zn}$ & 0.003 & 0.02 & 0 & 0 & 0 & 0.04 \\
\hline $\mathrm{Cd}$ & 0.01 & 0 & 0 & 0.01 & 0.01 & 0 \\
\hline $\mathrm{Pb}$ & 0.22 & 0 & 0 & 0.21 & 0 & 0.12 \\
\hline BOD & 0.1 & 0.1 & 0.2 & 0.1 & 0.2 & 0.2 \\
\hline COD & 2.8 & 2.3 & 2.1 & 1.8 & 1.8 & 3.1 \\
\hline Coli bacteria & $>2400$ & $>2400$ & $>2400$ & $>2400$ & $>2400$ & $>2400$ \\
\hline \multicolumn{7}{|c|}{25 May 2005 (dry season) } \\
\hline $\mathrm{NO}_{3}$ & 3 & 2.4 & 2 & 3 & 2.2 & 0 \\
\hline $\mathrm{NO}_{2}$ & 0 & 0 & 0 & 0 & 0.01 & 0 \\
\hline $\mathrm{Cr}_{6}$ & - & - & - & - & - & - \\
\hline $\mathrm{Cu}$ & - & - & - & - & - & - \\
\hline $\mathrm{Zn}$ & - & - & - & - & - & - \\
\hline $\mathrm{Cd}$ & - & - & - & - & - & - \\
\hline $\mathrm{Pb}$ & & & & & - & - \\
\hline BOD & 0.2 & 0.1 & 0.1 & 0.1 & 0.1 & 0.1 \\
\hline COD & 3.6 & 3.3 & 4.9 & 4.2 & 3.6 & 7.5 \\
\hline Coli bacteria & 75 & 20 & 7 & 21 & 9 & 1100 \\
\hline \multicolumn{7}{|c|}{ 20 September 2005 (dry season) } \\
\hline $\mathrm{NO}_{3}$ & 7.8 & 7.6 & 7.8 & 7.7 & 8.5 & 9.2 \\
\hline $\mathrm{NO}_{2}$ & 0.5 & 6.4 & 0 & 7.7 & 0 & 0 \\
\hline $\mathrm{Cr}_{6}$ & 0.4 & 0.31 & 0.29 & 0.35 & - & - \\
\hline $\mathrm{Cu}$ & - & - & - & - & - & - \\
\hline $\mathrm{Zn}$ & - & - & - & - & - & - \\
\hline $\mathrm{Cd}$ & - & - & - & - & - & - \\
\hline $\mathrm{Pb}$ & . & . & & & - & - \\
\hline BOD & - & - & - & - & 0.1 & 0.1 \\
\hline COD & 0.1 & 0.1 & 0.1 & 0.1 & 18 & 4.3 \\
\hline Coli bacteria & 2.3 & 1.1 & 25 & 1.1 & 23 & 75 \\
\hline
\end{tabular}

* Coli bacteria in MPN/100 ml, others in mg/l

$1=$ Pentung River $2=$ Tegoan River $3=$ Sumurup Sinkhole 4 : Suci Sinkhole $5=$ Bribin Cave $6=$ Baron Resurgence

By looking at Table 1 and according to the Water Quality Standard for Drinking Water issued by Indonesian Government, some parameters go beyond the standard i.e. heavy metals $(\mathrm{Cd}, \mathrm{Pb})$ and coli bacteria in Pentung sinkhole (Sample 1), $\mathrm{Pb}$ and coli bacteria in Tegoan River (Sample 2), heavy metals $\left(\mathrm{Cr}_{6}, \mathrm{~Pb}\right.$ ), BOD, coli bacteria in Sumurup sinkhole (sample 3), Cd, Pb, coli bacteria in Suci sinkhole (Sample 4). Furthermore, due to the occurrence of contaminants from the surface recharge, the water in Bribin and Baron Caves also contains some contamination parameters that exceed the drinking standard such as coli bacteria and COD in both caves, as well as heavy metal $\left(\mathrm{Cr}_{6}\right)$ in Baron Resurgence. The data also confirms that the level of contamination, especially for coli bacteria is higher in the rainy season.

\section{c. Contamination Source}

The sources of contaminants entering the allogenic rivers are: (1) organic and chemical fertilizer; (2) domestic waste disposed in the rivers; (3) husbandry waste disposal; (4) Wonosari City hospital waste; and (5) home industrial waste.

Next, farmers within conical karst recharge areas typically utilize organic fertilizers (from animals), that will be transported by overland-flow directly into the allogenic streams and karst point recharge (sinks). Consequently, the existence of contaminants, especially for coli bacteria, escalates during rainy season. This is demonstrated by the level of contaminants in almost all samples (see Table 1). In addition, the residents along the allogenic stream contribute to the increasing level of contamination due to their behavior in using river water for bathing and washing. In terms of domestic waste, the local residents characteristically dispose their domestic 
waste into conventional landfills without cementing or lining, sometimes very close to the allogenic streams and sinks. Besides that, industrial (produces heavy metals waste) and hospital waste from Wonosari City also seems to contribute to the increasing level of contamination in the underground system.

\section{Conclusion}

Some important phenomena that may be concluded are: (1) The most probable source of contamination of Bribin-Baron system is the disposal of waste from Wonosari urban area and its adjacent. Another possible contamination source are settlement areas within conical karst zones near the sinks. (2) The sources of contamination are agricultural-fertilizer waste, husbandry waste, industrial waste, and Wonosari Hospital waste. (3) Some contaminant parameters exceed the drinking standard as BOD, COD, heavy metals $\left(\mathrm{Cd}, \mathrm{Cr}_{6}, \mathrm{~Pb}\right)$, and coli bacteria.

\section{References}

ADJI, T. N. (2017, October 2). Spatial And Temporal Variation of Hidrogeochemistry And Karst Flow Properties To Characterize Karst Dynamic System In Bribin Underground River, Gunung Kidul Regency, Diy Province. Retrieved from osf.io/preprints/inarxiv/zegsa

ADJI, T.N. \& NURJANI, N., 1999, Optimasi Airtanah Karst Sebagai Pemasok Air Domestik Pada Kawasan Kritis Air di Gunung Kidul, Laporan Penelitian, Fakultas Geografi Universitas Gadjah Mada, Yogyakarta

ADJI, T.N. \& SUDARMADJI, 2010. Variasi Spasial-Temporal Hidrogeokimia dan Sifat Aliran Untuk Karakterisasi Sistem Karst Dinamis di Sungai Bawah Tanah Bribin, Kabupaten Gunung Kidul, DIY, Disertasi, Fakultas Geografi, Universitas Gadjah Mada, Yogyakarta

HARYONO, E. \& Adji, T.N. 2004. Geomorfologi dan Hidrologi Karst. Yogyakarta: Kelompok Studi Karst, Fakultas Geografi, Universitas Gadjah Mada

HARYONO, E. \& DAY, M. , 2004. Landform differentiation within the Gunung Kidul Kegel karst, Java, Indonesia, Journal of Cave and Karst Studies, 66-August

KUSUMAYUDHA, S.B., ZEN, M.T., 2000. Fractal analysis of the Oyo River, cave system and topography of the Gunung Sewu karst area, Central Java, Indonesia, Hydrogeology Journal, 8, 337-345

LEHMANN, H., 1936. Morfologische Studien auf Java, Gohr, Abh, 3, Stuttgart

MCDONALDS AND PARTNERS, 1984. Greater Yogyakarta - Groundwater Resources Study. Vol 1: Main Report. Yogyakarta, Directorate General of Water Resources Development Project (P2AT)

URUSHIBARA-YOSHINO, K., YOSHINO, M., 1997. Palaeoenvironmental change in Java Islands and its surrounding areas, Journal of Quaternary Science, 12 (5), 435-442 